\title{
The Issue of Alternative Assessment on Students' Achievement from the Viewpoints of Teachers' at Elementary Schools in Gaza
}

\author{
Mahmoud A.A. Almadhoun, Norsuhaily Abu Bakar, Abdul Hakim Abdullah
}

\begin{abstract}
This study aimed at identifying the effect of alternative assessment on academic achievement, from the viewpoint of teachers in elementary schools in Gaza. To achieve the study objectives, a questionnaire developed consisting of 21 items then reliability and validity were calculated, the study population consisted of 120 teachers. The study sample consisted of 92 teachers, selected in a stratified random method, where the total of 87 valid statistical analyzes retrieved by $94.56 \%$. The results of the study showed: The perceptions of the members of the study sample to the alternative assessment came to a high degree, the academic achievement from teachers in the basic schools in the Gaza Strip came at the macro level at a high level, and there is a statistically significant effect at the level of significance $(\alpha<=0.05)$ of alternative assessment on academic achievement. In light of the results, a set of recommendations were proposed, including The Directorate of Education in the Gaza Strip should be concerned with the adoption of alternative assessment methods in its affiliated schools, because of the importance of alternative assessment in improving the level of academic achievement of students.
\end{abstract}

Index Terms - Alternative assessment, students' achievement.

\section{INTRODUCTION}

The achievement of the student in the school and his ability to complete his education and beyond the multiple stages is entirely related to the level of academic achievement in the subjects, where the level of academic achievement of the student determines his future directions, as the student future depends on his/her academic achievement level in scientific materials or literary subjects.

Academic achievement is a specific level of achievement, or proficiency in school work measured by teachers, or by scheduled tests, and the scale on which to depend on the level of academic achievement is the total scores obtained by the student at the end of the school year, or at the end of the semester, after successfully passing the tests [1].

According to [2], academic achievement is the achievement of an educational or scholastic achievement of a particular subject. It means reaching a certain level of proficiency in a school or university study. The level of academic achievement is determined by a set of standardized tests or teacher reports or both.

\footnotetext{
Revised Manuscript Received on July 10, 2019.

Mahmoud A.A. Almadhoun, Faculty of Islamic Contemporary Studies, Universiti Sultan Zainal Abidin, Teremgganu, Malaysia.

Norsuhaily Abu Bakar, Faculty of Applied Social Sciences, Universiti Sultan Zainal Abidin, Teremgganu, Malaysia.

Abdul Hakim bin Abdullah, Faculty of Islamic Contemporary studies, Universiti Sultan Zainal Abidin, Teremgganu, Malaysia.
}

Academic achievement is usually calculated by means of ongoing examinations or assessment, but there is no agrees on the best way to test it or its most important characteristics whether procedural knowledge such as skills or explicit knowledge such as facts [3].

Therefore, teachers face a problem in choosing the appropriate method to test students' academic achievement. In addition, a new set of evaluation methods has emerged, called alternative assessment, which are based on the assumption that knowledge is configured and constructed by the learner, where this knowledge differs from one context to another [4].

Alternative assessment can also be defined as a trend in educational assessment based on putting students in real situations or simulating reality and monitoring their responses [5].

Based on the previous scenario, and the importance of academic achievement and the best methods of measuring it, the idea of this study was to measure the impact of alternative assessment on the academic achievement of school students.

\section{A. Research Problems}

The evaluation is an essential part of the educational process and an integral part of it. It is the means by which to know what has been achieved, and to what extent the results are consistent with the effort exerted by individuals at different levels and with the possibilities used. Through the evaluation, the positive and negative aspects of the educational process can be identified, and weaknesses and shortcomings identified in order to take appropriate action. Several studies in student assessment [4], [6] have indicated that the traditional assessment used in most schools cannot properly measure students' level, so it is necessary to move to more effective alternative assessment methods.

Despite the importance of the assessment in our schools, it has become synonymous with the concept of examinations, so that it measures the cognitive aspect of students without attention to other aspects of student growth. According to [7], traditional exams don't taking into account the higher levels of knowledge, where it focus on some aspects not all, this reason made it not suitable for determine the real level for students. This led the researcher to identify the views of teachers of alternative assessment methods,

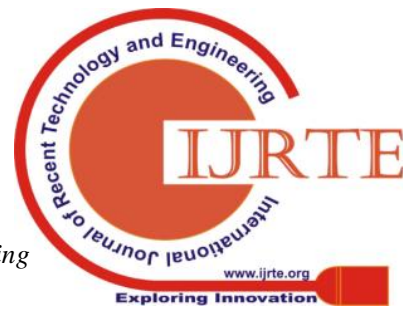




\section{THE ISSUE OF ALTERNATIVE ASSESSMENT ON STUDENTS' ACHIEVEMENT FROM THE VIEWPOINTS OF TEACHERS' AT ELEMENTARY SCHOOLS IN GAZA}

which depends on the assumption that knowledge is created and built by the learner and its impact on the academic achievement of students in elementary schools in the Gaza Strip.

The research problem can be identified by the following main question:

What is the impact of the use of alternative assessment methods on the academic achievement of primary school students in Gaza from the point of view of teachers?

\section{B. Research Objectives}

The research seeks to achieve the following objectives: To identify the level of teachers' use of alternative assessment methods at primary school in the Gaza Strip. To measure the impact of alternative assessment methods on the level of academic achievement of primary school students in the Gaza Strip.

\section{Research Questions}

The research seeks to answer the following questions: What is the level of teachers' use of alternative assessment methods in elementary schools in the Gaza Strip?

What is the impact of the use of alternative assessment methods on the academic achievement of primary school students in the Gaza Strip?

\section{LITERATURE REVIEW}

Many educational systems have relied on tests as a means of evaluating students in different educational stages in schools. But finally, this method has been met with wide criticism by educational experts. So, those interested in scientific studies began to look for new ways of assessment that are more diverse and accurate in determining the level of students and help in developing the mental abilities of students.

\section{A. The Concept and Implementation of Alternative Assessment}

The assessment is a systematic process based on scientific principles, aimed at making a precise and objective judgment on the inputs, processes, and outputs of any educational system, and then identifying strengths and shortcomings in each of them in order to make appropriate decisions to redress weaknesses and shortcomings [8].

The ultimate goal of the evaluation process is to improve the learning process, as [6] emphasizes that improving learning is the ultimate goal of the assessment process, where the evaluation of student performance aims to identify the strengths and weaknesses in their performance in preparation for the treatment of weaknesses and the emphasis on the strengths and support. Therefore, the purpose of the assessment is not for determining the level of students.

The researcher points out that, assessment is an essential component of the educational process. It is the process by which the success of achieving the educational goals can judge and the extent to which the students achieve these goals. The teacher resorts to evaluation after the program ends and a period may be extended or shortened.

Also, assessment has become a major focus of the educational process, and its functions and types have evolved considerably, where the use of assessment models is a distinct modern trend in the 1970s. While, the late of 1980s and early 1990s, new concepts have emerged such as performance assessment and alternative assessment [7]

Alternative assessment defined as an assessment based on the assumption that knowledge is configured and constructed by the learner, as that knowledge differs from one context to another. The idea of this type of assessment is depending on the possibility of creating an integrated picture of the learner in the light of a set of alternatives, some or all [6]

Besides, the alternative assessment reflects a trend in the educational evaluation based on placing students in real situations or simulating reality and monitoring their responses [5].

The alternative assessment measures student performance in real situations as close as possible to reality, through performing tasks and assignments similar to those outside of school, where real assessment prepares students for life. It is realistic because it requires the student to accomplish tasks that have meaning, and needs in real life, and includes solving life problems [6].

The alternative assessment has led to radical changes in the philosophy of education in general, and the evaluation of students' achievement and opinions, [7] noted three major shifts in alternative assessment, as follows:

The transition from testing policy to multiple evaluation policies. The shift from cognitive capacity policy to multicapacity assessment. Shift from a separate evaluation to an integrated assessment.

Alternative assessment has a variety of strategies, such as performance-based evaluation, self-assessment, paper, and pen assessment, and assessment by observation [7].

\section{B. Academic Achievement}

Academic achievement is a set of educational goals that are achieved by the student, and is strongly related to the mental ability of the student, which reflects the ability of the student to accomplish a particular work through the actions of sensory and mental, where this ability varies from person to person [2].

Academic achievement measures the number of scientific concepts among students, which is one of the most important indicators on which educational systems are based to measure the amount of learning. It is an indicator of the extent to which the educational goals achieved. It is used to indicate the level of success achieved by the students in their field of study. Also, it represents the acquisition of knowledge, skills and the ability to use them in current or future situations [1].

Achievement tests are used as a means of evaluation by educational systems to ensure that the objectives of the program achieved. Achievement tests are the most important part of the school's assessment and measurement program [8].

The concept of academic achievement is to measure the student's ability to absorb the required subjects and the 
extent of their ability to apply them through means of measurement conducted by the school through oral and written examinations that take place at different times wither daily and quarterly examinations [3].

There are a number of factors that affect the amount of academic achievement of the student, which classified into three main groups; the first group of factors that relate to the same person, and the second group related to the surrounding environment and the family, while the final group contains a numbers of factors related to school [1].

Besides, academic achievement is a multivariate phenomenon, which linked to a large number of factors, including cognitive, motivational, emotional and other personality components. The educational achievement also influenced by social and cultural variables related to the environment (school and family) in which students live [2].

\section{METHODOLOGY}

This research based on the descriptive analytical approach, through reference to the theoretical literature related to the current research topic, in addition to developing a questionnaire as the main tool for collecting data from the sample of the study.

\section{A. Population and Sample}

The research population is composed of all (120) teachers from five selected elementary school in the Gaza Strip. A random sample selected according to [9], a sample of 92 teachers is enough to represent 120 teachers from the selected schools. Total of (92) questionnaires were distributed to the teachers. A total of (87) questionnaires were retrieved, representing $(94.56 \%)$ of the total distributed questionnaires, which is acceptable for scientific research purposes.

\section{B. Research Instrument}

To achieve the objectives, a questionnaire was developed based on the five-point Likert scale, ranging from "Strongly Agree" and "Strongly Disagree" to a relative weight (5-1). It included three sections, as follows: The first section deals with the level of teachers' use of alternative assessment methods in elementary schools. The second section deals with the alternative evaluation variable and each dimension, while the third section includes the academic achievement variable. Where the development of this tool based on many studies [1], [6], [5]. To verify the validity of the research tool, the validity of the content used by presenting it to a group of experienced and competent arbitrators related to the current research subject. The recommendations of the arbitrators were not to delete any paragraph, with the reformulation of some paragraphs in the research tool.

Also, the stability of the search tool was confirmed using the coefficient of internal consistency based on Cronbach's Alpha equation. The internal consistency coefficient of the search tool extracted by distributing it to a random sample of 10 teachers. The stability coefficient of the alternative assessment variable was (0.82), while the coefficient of stability of the academic achievement variable was $(0.85)$.

\section{RESULTS AND DISCUSSION}

The results of this study as follows:

First Question: What is the level of teachers' use of alternative assessment methods in elementary schools in Gaza Strip? To answer this question, the arithmetical averages and the standard deviations calculated for the respondents' assessment of the level of alternative assessment among the teacher's at elementary schools in Gaza Strip, at the level of each item and the total items.

Table 1: Computational and standard deviations of the level of use of alternative assessment from teachers

\begin{tabular}{|c|c|c|c|}
\hline & $\mathrm{N}$ & Mean & S.D. \\
\hline $\begin{array}{l}\text { The use of alternative assessment } \\
\text { increases the level of student } \\
\text { achievement effectively. }\end{array}$ & 87 & 4.3448 & .87375 \\
\hline $\begin{array}{l}\text { Alternative assessment allows } \\
\text { teachers to evaluate the } \\
\text { effectiveness of their lessons on } \\
\text { students' knowledge. }\end{array}$ & 87 & 3.6897 & 1.23241 \\
\hline $\begin{array}{l}\text { Alternative assessment allows } \\
\text { teachers to evaluate the } \\
\text { effectiveness of their lessons on } \\
\text { students' skills. }\end{array}$ & 86 & 3.6977 & 1.09619 \\
\hline $\begin{array}{l}\text { Alternative assessment allows } \\
\text { teachers to evaluate the } \\
\text { effectiveness of their lessons on } \\
\text { students' attitudes. }\end{array}$ & 87 & 4.2299 & .99652 \\
\hline $\begin{array}{l}\text { Alternative assessment helps me to } \\
\text { identify students' strengths and } \\
\text { weaknesses. }\end{array}$ & 87 & 4.3333 & .89789 \\
\hline $\begin{array}{l}\text { Alternative assessment can be used } \\
\text { to assess individual student } \\
\text { performance constantly. }\end{array}$ & 86 & 4.2907 & .98059 \\
\hline $\begin{array}{l}\text { Alternative assessment can promote } \\
\text { active learning among students. }\end{array}$ & 87 & 4.1609 & .95081 \\
\hline $\begin{array}{l}\text { Alternative assessment can promote } \\
\text { self confidence among students. }\end{array}$ & 87 & 3.4138 & 1.33427 \\
\hline $\begin{array}{l}\text { Alternative assessment can } \\
\text { encourage students in critical, } \\
\text { analytical and creative thinking. }\end{array}$ & 86 & 3.9767 & 1.12696 \\
\hline $\begin{array}{l}\text { Alternative assessment emphasizes } \\
\text { on real life skills such as problem } \\
\text { solving skills. }\end{array}$ & 86 & 3.8140 & 1.10093 \\
\hline $\begin{array}{l}\text { Alternative assessment emphasizes } \\
\text { on real life skills such as decision } \\
\text { making skills. }\end{array}$ & 87 & 4.1954 & .95039 \\
\hline Total & 87 & 4.0146 & .70610 \\
\hline
\end{tabular}

Table 1 shows that the mean for the level of the alternative assessment from teachers in the basic schools in the Gaza Strip came at the macro level at a high level with the mean (4.01) and a standard deviation of (.70). Also, data from the above table showed that, at the level of items, the item "I Encourage students to practice self-assessment" ranked first, with the mean (4.34), while at the last rank came the item "I use written

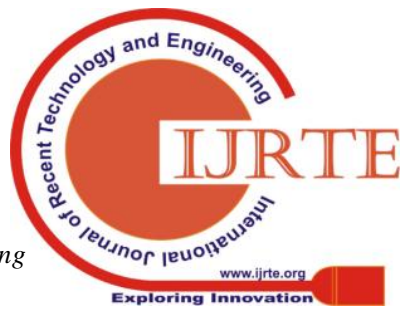


tests to evaluate student performance" with mean (3.41). Second Question:

Table 2: Computational and standard deviations of the level of use of alternative assessment from teachers

\begin{tabular}{|l|c|l|c|}
\hline & $\mathrm{N}$ & Mean & S.D. \\
\hline $\begin{array}{l}\text { Students are anxious to have } \\
\text { distinguished academic } \\
\text { achievement. }\end{array}$ & 87 & 3.9425 & 1.16496 \\
\hline $\begin{array}{l}\text { Students have developed their } \\
\text { academic achievement }\end{array}$ & 87 & 4.0575 & 1.07136 \\
\hline $\begin{array}{l}\text { Student can increase their } \\
\text { academic achievement in all } \\
\text { subjects. }\end{array}$ & 86 & 3.9535 & 1.07273 \\
\hline $\begin{array}{l}\text { Students can improve their } \\
\text { knowledge from the lessons. }\end{array}$ & 87 & 3.4535 & 1.24293 \\
\hline $\begin{array}{l}\text { Students can improve their skills } \\
\text { from the lessons. }\end{array}$ & 87 & 4.1279 & 1.03806 \\
\hline $\begin{array}{l}\text { Students can improve their } \\
\text { attitudes toward the lessons. }\end{array}$ & 86 & 4.2558 & 1.03112 \\
\hline $\begin{array}{l}\text { Students can think on their own } \\
\text { and become confident and active } \\
\text { learners. improved their }\end{array}$ & 87 & 4.1379 & 1.08019 \\
\hline $\begin{array}{l}\text { Students have improved } \\
\text { critical, analytical and creative } \\
\text { thinking. }\end{array}$ & 4.3023 & .92125 \\
\hline $\begin{array}{l}\text { Students have improved their } \\
\text { problem solving skills. }\end{array}$ & 86 & 4.0920 & 1.14762 \\
\hline $\begin{array}{l}\text { Students have improved their } \\
\text { decision making skills. }\end{array}$ & 86 & 4.1279 & 1.03806 \\
\hline Total & 87 & 4.0408 & .80517 \\
\hline
\end{tabular}

Table 2 shows that the mean for the level of the academic achievement from teachers in the basic schools in the Gaza Strip came at the macro level at a high level with the mean (4.04) and a standard deviation of (.80).

Third Question: What is the impact of the use of alternative assessment methods on the level of academic achievement of primary school students in the Gaza Strip?

Before applying the regression analysis to answer the second question, some tests were carried out to ensure the adequacy of the data for the regression analysis. It ascertained that there was no high correlation between the independent variables (multicollinearity) using Variance Inflation Factory (VIF) and tolerance test for each of the study variables. Taking into consideration that the VIF is not exceeded of the (10) value. Also, the tolerance test value is greater than 0.05 , and the normal distribution is also calculated by calculating the skewness coefficient, considering that the data follow the natural distribution if the value of the torsion coefficient is close to 0 . Table 3 shows the results of these tests.

Table 3: Results of variance inflation factory, skewness coefficient, and tolerance test

\begin{tabular}{|c|c|c|c|}
\hline Independent Variable & VIF & Tolerance & Skewness \\
\hline Alternative Assessment & 1.00 & 0.967 & 0.619 \\
\hline
\end{tabular}

From the above table, the data showed that the value of the VIF test is less than 10, and the tolerance test value is (1), which is greater than (0.05), this indicates that there is no high correlation between the independent variables (multicollinearity). Also, it ascertained that the data followed the natural distribution by calculating the skewness coefficient, where the value was close to (0) means less than (1), so it can said that there is no real problem with the normal distribution of the study data.

Besides, the validity of the model verified by using Analysis of Variance, and Table 4 shows the results.

Table 4: Results of analysis of variance to verify the validity of the study model

\begin{tabular}{|c|c|c|c|}
\hline $\begin{array}{c}\text { Dependent } \\
\text { Variable }\end{array}$ & Source & $\mathrm{R}^{2}$ & Sum of Squares \\
\hline $\begin{array}{c}\text { Academic } \\
\text { Achievement }\end{array}$ & $\begin{array}{c}\text { Regression } \\
\text { Error }\end{array}$ & .619 & $44.904,10.850$ \\
\hline Mean Squares & $\mathrm{F}$ & Sig & \\
\hline $\begin{array}{c}1.449 \\
0.97\end{array}$ & 7.343 & .000 & \\
\hline
\end{tabular}

Table 4 shows the validity of the study model, in terms of the calculated value of $F$ and its associated level of significance at the level of $(\alpha . \leq 0.05)$. The alternative assessment as a whole explains $(61.9 \%)$ of the variance in the total dependent variable (academic achievement). This confirms the impact of the alternative assessment on the interpretation of academic achievement, and therefore we can answer the second question as follows.

Table 5: Multiple regression analysis results to assess the effect of alternative assessment on academic achievement

\begin{tabular}{|c|c|c|}
\hline Independent Variable & B & Std. Error \\
\hline Alternative Assessment & .897 & 0.76 \\
\hline Beta & T & Sig. \\
\hline 0.787 & 11.753 & 0.000 \\
\hline
\end{tabular}

The statistical results in Table 5, follow-up the values of (beta), and (t) show that the independent variable (alternative evaluation) has an impact on academic achievement, in terms of the beta coefficients of this variable as shown in the table, and in terms of the increase in the value of $(t)$ at the level of significance $(\alpha . \leq 0.05)$.

\section{CONCLUSION}

\section{A. Discuss the Results Related to the First Question}

The results of the first question showed that the mean for the level of the alternative assessment from teachers in the basic schools in the Gaza Strip came at the macro level at a high level with a mean (4.01). The researcher attributes this result to that alternative assessment provides teachers and students with feedback to use in reviewing their performance or similar work.

Also, the importance of this strategy lies in the teacher's knowledge of strengths and weaknesses in the performance of students, and the measurement of the level of achievement and progress, which provides the teacher 
and the guardian feedback on their performance. Therefore, we note that teachers strongly desire to apply alternative assessment methods to provide them with assistance in evaluating the performance of students in real and integrated.

\section{B. Discuss the Results Related to the Second Question}

The result of the second question showed that the independent variable (alternative evaluation) has an impact on academic achievement, the researcher attributes this result to that the alternative assessment provides an integrated picture of the learners, including the knowledge and skills and trends and the ability to employ what they learned in practical situations, using a set of alternatives that measure the real performance of the student and not just achievement based on tests paper and pen and the importance of using the file. It is important to achieve educational goals, identify the abilities of the student's, increase their participation in activities, reduce fear and anxiety, develop the ability to self-learning, and methods of scientific thinking.

Also, the researcher due to this result to that, the alternative assessment focuses on assessing the learner's ability to perform high-level real-life tasks similar to those that will exposed in his future life, and try to provide a comprehensive picture of the learner in all aspects of the educational process.

\section{Recommendations}

In light of the results, the researcher recommended that:

- The Directorate of Education in the Gaza Strip should be concerned with the adoption of alternative assessment methods in its affiliated schools, because of the importance of alternative assessment in improving the level of academic achievement of students.

- Preparation of seminars and educational programs that illustrate the various methods of alternative assessment for school teachers, to determine the alternative evaluation and its impact on the level of academic achievement among students

\section{REFERENCES}

1. M. Dev, "Factors affecting the academic achievement: A study of elementary school students of NCR Delhi, India," Journal of Education and Practice, 7(4), 2016, pp. 70-74.

2. A. R. Damavandi, Mahyuddin, H. Elias, S. Daud, and J. Shabani, "Academic achievement of students with different learning styles," International Journal of Psychological Studies, 3(2), 2011, pp. 186-192.

3. P. Kpolovie, I. Joe, and T. Okoto, "Academic achievement prediction: Role of interest in learning and attitude towards school," National Journal of Humanities Social Sciences and Education, 1(11), 2014, pp. 73-100.

4. N. Nasri, S. N. Roslan, M. I. Sekuan, K. A. Bakar, and S. N. Puteh, "Teachers' perception on alternative assessment," Procedia Social and Behavioral Sciences, 7, 2010, pp. 37-42.

5. E. Kirikkaya, and G. Vurkaya, "The effect of using alternative assessment activities on students' success and attitudes in science and technology course," Educational Sciences: Theory and Practice, 11(2), 2011, pp. 997-1004.
6. S. Aliasin, and M. Amanlu, "The effect of alternative assessment techniques on EFL learners' reading comprehension ability and self-efficacy in reading: The case of Iranian Junior High School students", Linguistics and Literature Studies, 5(3), 2017, pp. 160-168.

7. L. Hung, "Alternative assessment: Can portfolio assessment have positive impact on EFL aboriginal students' learning outcome," International Journal of Management and Applied Science, 2(9), 2016, pp. 139-144.

8. H. K. Tyagi, and A. Kumar, "Influence of general mental ability, study habits, reading ability and SES on achievements of students," International Journal of Education and Extension, 2(2), 2014, pp. 117-124.

9. C. Janisch, X. Liu, and A. Akrofi, "Implementing alternative assessment: Opportunities and obstsacles," The Educational Forum, 71(3), 2007, pp. 221-230. 